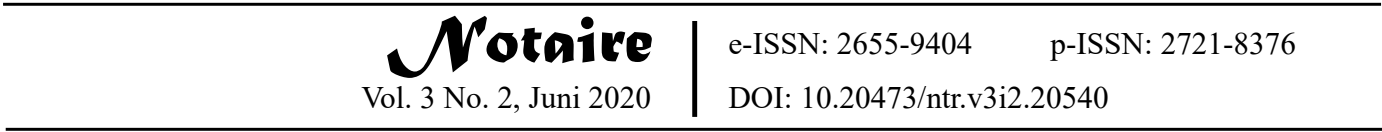

Article history: Submitted 20 April 2020 ; Accepted 2815 May 2020; Available online 1 June 2020.

\title{
Keabsahan Pemungutan Pajak Penghasilan Terhadap Koperasi
}

\author{
Roidah Zahiroh \\ roidahzahiroh@gmail.com \\ Universitas Airlangga
}

\begin{abstract}
To improve the quality of cooperation in Indonesia, the Ministry of Cooperation, Micro small and Medium Enterprises runs the Cooperation Total Reform program through three strategic steps, namely Reorientation, Rehabilitation and Development. One of the development steps to strengthen cooperatives undertaken by the government is to reduce cooperative corporation tax with the enactment of Government Regulation Number 23 Year 2018. This government regulation is a substitute regulation for Government Regulation Number 46 Year 2013 which regulates the Final Income Tax Government Regulation Number 46 Year 2013 does not reflect justice and detrimental to the Corporate tax payers especially Cooperation. There are many changes regulated in this Government Regulation, one of them is the reduction in tariff and adjustments criteria for Corporate Tax payers, which directly states that cooperation are one of the Corporate Tax payer. This research is legal research using a statute approach and conceptual approach. The result of this legal research, it is known that the collection of income tax on cooperation entities has fulfilled the aspect of justice, because after the enactment of Government Regulation Number 23 Year 2018 and PMK Number 99/ PMK.03/2018 the arrangements regarding cooperation corporate income tax rates are distinguished based on the amount of turnover in one tax year and given the option to follow the corporate income tax rate scheme based on general income tax provisions or based on PP Number 23 of 2018.

Keywords: Corporate Income Tax; Final Income Tax; Government Regulation Number 23 Year 2018; Cooperation.
\end{abstract}

\section{Abstrak}

Untuk meningkatkan kualitas koperasi di Indonesia, Kementerian Koperasi dan UKM menjalankan program Reformasi Total Koperasi melalui tiga langkah strategis, yakni dengan Reorientasi, Rehabilitasi dan Pengembangan. Salah satu langkah Pengembangan untuk memperkuat koperasi yang dilakukan pemerintah adalah dengan menurunkan pajak badan koperasi dengan diberlakukannya PP Nomor 23 Tahun 2018. Peraturan pemerintah ini merupakan peraturan pengganti PP Nomor 46 Tahun 2013 yang mengatur mengenai Pajak Penghasilan Final. PP Nomor 46 Tahun 2013 dinilai tidak mencerminkan keadilan dan merugikan bagi Wajib Pajak Badan. Terdapat banyak perubahan yang diatur di dalam PP Nomor 23 Tahun 2018 salah satunya adalah penurunan tarif dan penyesuaian kriteria Wajib Pajak Badan yang di dalamnya disebutkan secara langsung bahwa koperasi merupakan salah satu Wajib Pajak Badan. Penelitian ini merupakan penelitian hukum yang disusun dengan menggunakan pendekatan peraturan perundang-undangan dan pendekatan konseptual. Dari penelitian hukum ini, diketahui bahwa dalam pemungutan pajak penghasilan terhadap badan koperasi telah memenuhi aspek keadilan, karena setelah diberlakukannya PP Nomor 23 Tahun 2018 dan PMK Nomor 99/PMK.03/2018 pengaturan mengenai tarif pajak penghasilan badan koperasi dibedakan berdasarkan jumlah omzet dalam satu tahun pajak serta diberikan pilihan untuk mengikuti skema tarif pajak penghasilan badan berdasarkan ketentuan umum pajak penghasilan atau berdasarkan skema PP Nomor 23 Tahun 2018.

Kata Kunci: Pajak Penghasilan Badan; Pajak Penghasilan Final; PP Nomor 23 Tahun 2018; Koperasi. 


\section{Pendahuluan}

Berlandaskan pada Pasal 23A Undang-Undang Dasar Negara Republik Indonesia Tahun 1945 yang menyatakan bahwa: "Pajak dan pungutan lain yang bersifat memaksa untuk keperluan negara diatur dengan undang-undang" maka dibentuklah peraturan perundang-undangan tersendiri mengenai perpajakan untuk menjamin kepastian hukum terhadap pemungutan pajak. Pemungutan pajak merupakan peralihan kekayaan dari rakyat kepada negara yang hasilnya juga akan dikembalikan kepada masyarakat. ${ }^{1}$ Bila ada pungutan yang namanya pajak tetapi tidak berdasarkan undang-undang, maka pungutan tersebut bukanlah pajak, tetapi lebih tepat disebut sebagai perampokan (taxaxion without representation is robbery). ${ }^{2}$

Selain pajak harus dipungut berdasarkan undang-undang, dalam menyusun undang-undangnya nyata-nyata harus diusahakan oleh pembuat undang-undang tercapainya keadilan dalam pemungutan pajak dengan mengindahkan keempat unsur dari Adam Smith's Canon (asas Equality (keadilan), asas Certainly (kepastian hukum), asas Convenience of Payment (Pemungutan Pajak Tepat Waktu), dan asas Eficiency/Economic of Collections (Efisiensi)). ${ }^{3}$ Secara umum ada hal-hal yang tidak boleh dilupakan. Pertama, hak-hak fiskus yang telah diberikan harus dijamin dapat terlaksana dengan lancar, telah diketahui oleh umum, bahwa dalam praktiknya para wajib pajak suka mencoba dengan secara legal atau tidak, untuk menghindarkan diri dari yang telah ditentukan oleh Undang-Undang Pajak, keadilan semacam ini harus diatasi dengan penyempurnaan peraturan-peraturan dalam undangundang dilengkapi dengan sanksi-sanksinya. Kedua, wajib pajak harus pula mendapatkan jaminan hukum, perlindungan hukum, agar tidak diperlakukan dengan sewenang-wenang oleh fiskus dengan aparaturnya, sehingga segala sesuatu harus diatur dengan terang dan tegas. ${ }^{4}$

\footnotetext{
${ }^{1}$ Wirawan B Ilyas dan Richard Burton, Hukum Pajak (Salemba Empat 2010).[7].

2 ibid.[7].

3 Adrian Sutedi, Hukum Pajak (Sinar Grafika).[25].

4 ibid.[26].
} 
Di dalam Pasal 1 angka 3 Undang - Undang Nomor 28 Tahun 2007 tentang Perubahan Ketiga atas Undang - Undang Nomor 6 Tahun 1983 tentang Ketentuan Umum dan Tata Cara Perpajakan (KUP) menyatakan bahwa Badan adalah sekumpulan orang dan/atau yang merupakan kesatuan baik yang melakukan usaha maupun yang tidak melakukan usaha yang meliputi perseroan terbatas, perseroan komanditer, perseroan lainnya, badan usaha milik negara atau badan usaha milik daerah dengan nama dan dalam bentuk apa pun, firma, kongsi, koperasi, dana pensiun, persekutuan, perkumpulan, yayasan, organisasi massa, organisasi politik atau organisasi lainnya, lembaga dan bentuk badan lainnya termasuk kontrak investasi kolektif dan bentuk usaha tetap. Serta di dalam Pasal 2 ayat (1) huruf b Undang-Undang Nomor 36 tahun 2008 Tentang Pajak Penghasilan menyatakan bahwa salah satu subjek pajak adalah Badan. Dari ketentuan kedua pasal tersebut diketahui bahwa koperasi termasuk sebagai subjek pajak Badan sehingga koperasi merupakan wajib pajak Badan yang wajib mematuhi dan melaksanakan kewajiban perpajakan yang diatur di dalam peraturan perundangundangan sebagai salah satu sumber pemasukan kas negara yang nantinya digunakan untuk kesejahteraan masyarakat.

Koperasi memiliki peran strategis terhadap pertumbuhan ekonomi dan pemerataan kesejahteraan masyarakat. Koperasi juga dapat menjalankan peran sebagai pemutus mata rantai kesenjangan di kalangan masyarakat. Sebagaimana tujuan koperasi yang tercantum di dalam Pasal 3 Undang-Undang Republik Indonesia Nomor 25 Tahun 1992 tentang Perkoperasian yakni memajukan kesejahteraan anggota khususnya dan masyarakat pada umumnya serta ikut membangun tatanan perekonomian nasional dalam rangka mewujudkan masyarakat yang maju, adil dan makmur berlandaskan Pancasila dan UndangUndang Dasar 1945. Oleh karena itu koperasi harus tumbuh berkualitas agar kontribusi terhadap pemerataan semakin besar. Kontribusi koperasi terhadap pertumbuhan ekonomi nasional tercermin dari Produk Domestik Bruto (PDB) koperasi. Menurut Kementerian Koperasi dan UKM, tren PDB koperasi terus bertumbuh. Pada Tahun 2014 PDB koperasi hanya tercatat 1,71\%, kemudian 
pada Tahun 2017 melonjak menjadi 4,48\% dan pada 2018 naik ke angka 5,1\%. Peningkatan PDB koperasi tersebut sejalan dengan adanya langkah peningkatan kualitas koperasi di Indonesia oleh pemerintah.

Untuk meningkatkan kualitas koperasi di Indonesia, Kementerian Koperasi dan UKM menjalankan program Reformasi Total Koperasi melalui tiga langkah strategis, yakni dengan Reorientasi, Rehabilitasi dan Pengembangan. Langkah Pengembangan merupakan langkah yang dilakukan pemerintah guna meningkatkan kapasitas koperasi sebagai badan usaha berbasis anggota yang sehat, kuat, mandiri, tangguh serta setara dengan badan usaha lainnya melalui regulasi yang kondusif, perkuatan sumber daya manusia, kelembagaan, pembiayaan, pemasaran dan kemajuan teknologi. Contoh langkah Pengembangan untuk memperkuat koperasi yang dilakukan pemerintah adalah dengan menurunkan pajak badan koperasi. ${ }^{6}$

Pada Bulan Juli Tahun 2013, Pemerintah telah mengeluarkan Peraturan Pemerintah Republik Indonesia Nomor 46 Tahun 2013 tentang Pajak Penghasilan atas Penghasilan dari Usaha yang Diterima atau Diperoleh Wajib Pajak yang Memiliki Peredaran Bruto Tertentu sebagai upaya untuk mengintensifkan peran serta semua pelaku kegiatan ekonomi untuk membayar pajak, tak terkecuali koperasi. Kemudian Peraturan Pemerintah tersebut digantikan dengan Peraturan Pemerintah Republik Indonesia Nomor 23 Tahun 2018 Tentang Pajak Penghasilan Atas Penghasilan Dari Usaha yang Diterima Atau Diperoleh Wajib Pajak Yang Memiliki Peredaran Bruto Tertentu yang mulai berlaku tanggal 1 Juli 2018 hingga saat ini. Peraturan Pemerintah tersebut merupakan peraturan pelaksana dari Pasal 4 ayat (2) huruf e Undang-Undang Republik Indonesia Nomor 36 Tahun 2008 Tentang Pajak Penghasilan. Pada dasarnya peraturan ini mengatur mengenai pengenaan PPh Final Pasal 4 Ayat (2) bagi wajib pajak yang memiliki peredaran

${ }^{5}$ Gabriella Thesa Widiari, ‘PDB Koperasi Indonesia Terus Meningkat' (Gesuri.id, 2019) <https://www.gesuri.id/pemerintahan/pdb-koperasi-indonesia-terus-meningkat-b1WcBZimr>. accessed 2 Agustus 2019.

6 Media Indonesia, 'Empat Tahun Reformasi Total Koperasi' (Media Indonesia, 2018) <https:// mediaindonesia.com/read/detail/191881-empat-tahun-reformasi-total-koperasi>.accessed 2 Agustus 2019. 
bruto (omzet) sampai dengan Rp 4,8 Miliar dalam satu tahun pajak. PPh final merupakan pajak penghasilan yang langsung dikenakan saat menerima objek atau sumber penghasilan tertentu dan tidak akan diperhitungkan kembali di dalam SPT Tahunan PPh, namun perlu dituliskan ke dalam formulir SPT Tahunan.

Peraturan terbaru tersebut selain menyatakan secara langsung di dalam pasalnya bahwa koperasi termasuk sebagai Wajib Pajak Penghasilan Final, juga menurunkan tarif PPh Final yang awalnya 1\% menjadi 0,5\% dari omzet yang wajib dibayarkan setiap bulannya, PP ini juga mengatur mengenai jangka waktu pengenaan tarif PPh Final 0,5\% sebagai berikut:

a. Bagi Wajib Pajak Orang Pribadi yaitu selama 7 tahun;

b. Bagi Wajib Pajak Badan berbentuk Koperasi, Persekutuan Komanditer, atau Firma selama 4 tahun;

c. Bagi Wajib Pajak Badan berbentuk Perseroan Terbatas selama 3 tahun.

PP Nomor 23 Tahun 2018 juga memberikan pilihan kepada Wajib Pajak dengan peredaran bruto tertentu untuk mengikuti tarif dengan skema final 0,5\%, atau menggunakan skema normal yang mengacu pada Pasal 17 Undang-Undang Nomor 36 Tahun 2008 tentang Pajak Penghasilan sehingga koperasi yang memiliki peredaran bruto tertentu dapat memilih untuk dikenai Pajak Penghasilan Final atau Pajak Penghasilan Badan berdasarkan Ketentuan Umum Pajak Penghasilan. Pemberlakuan aturan baru ini merupakan salah satu upaya pemerintah dalam menjalankan langkah Pengembangan untuk memperkuat eksistensi koperasi di Indonesia. Dengan diberlakukannya PP Nomor 23 Tahun 2018 yang memberikan kemudahan kepada para pelaku usaha termasuk koperasi sehingga beban pajak yang ditanggung oleh pelaku usaha yang dikenakan Pajak Penghasilan final menjadi lebih kecil, maka para pelaku usaha tersebut diharapkan memiliki kemampuan ekonomi yang lebih besar untuk mengembangkan usahanya.

Kontribusi pembayaran pajak dari wajib pajak berbentuk koperasi, usaha kecil dan menengah saat ini masih sangat kecil dibandingkan total penerimaan pajak, padahal jumlah koperasi, usaha kecil dan usaha menengah sangat banyak. Pengetahuan terkait perpajakan merupakan suatu hal penting bagi wajib pajak, 
kurangnya pemahaman akan ketentuan perpajakan terutama perkembangan regulasi perpajakan yang banyak mengalami perubahan dan kurangnya sosialisasi dari pemerintah tentang banyaknya fasilitas perpajakan yang tujuannya mendorong sektor usaha kecil dan menengah, kemungkinan dapat menjadi penyebab rendahnya kontribusi penerimaan pajak dari sektor koperasi dan usaha kecil dan menengah. Rendahnya kesadaran wajib pajak untuk menjalankan kewajibannya inilah yang menjadi salah satu faktor yang akan menyebabkan terhambatnya pelaksanaan pemerataan kesejahteraan masyarakat.

\section{Dasar Landasan Pemungutan Pajak Penghasilan Terhadap Koperasi}

Secara yuridis pengakuan koperasi tercantum di dalam Pasal 33 ayat (1) UUD NRI 1945 yang menyatakan bahwa "perekonomian harus disusun sebagai usaha bersama berdasar atas asas kekeluargaan", meskipun pasal tersebut tidak menyebutkan koperasi secara langsung, namun Mohammad Hatta menafsirkan bahwa asas kekeluargaan yang tercantum di dalam pasal tersebut ialah koperasi. ${ }^{7}$ Dengan adanya Pasal 33 ayat (1) UUD NRI 1945 maka koperasi diakui sebagai salah satu pelaku ekonomi di Indonesia yang kemudian diberikan kesempatan untuk melakukan kegiatan usaha seperti pelaku ekonomi lainnya sebagaimana ditegaskan di dalam Pasal 61 UU Nomor 25 Tahun 1992 tentang Perkoperasian yang menyatakan "dalam upaya menciptakan dan mengembangkan iklim dan kondisi yang mendorong pertumbuhan dan permasyarakatan koperasi, salah satunya adalah Pemerintah memberikan kesempatan usaha yang seluas-luasnya kepada koperasi".

Berdasarkan ketentuan di dalam Undang-Undang Nomor 28 Tahun 2007, yang termasuk sebagai Subjek Pajak adalah orang pribadi, warisan yang belum terbagi sebagai satu kesatuan menggantikan yang berhak, badan yang terdiri dari perseroan terbatas, perseroan komanditer, perseroan lainnya, badan usaha milik negara atau badan usaha milik daerah dengan nama dan dalam bentuk apa

7 Muslimin Nasution, Koperasi Menjawab Kondisi Ekonomi Nasional (Pusat Informasi perkoperasian 2008).[166]. 
pun, firma, kongsi, koperasi, dana pensiun, persekutuan, perkumpulan, yayasan, organisasi massa, organisasi politik atau organisasi lainnya, lembaga dan bentuk badan lainnya termasuk kontrak investasi kolektif serta bentuk usaha tetap.

Pasal 2 ayat (1) huruf b Undang-Undang Nomor 36 tahun 2008 tentang Pajak Penghasilan menyatakan bahwa Subjek Pajak Penghasilan adalah orang pribadi, warisan yang belum terbagi sebagai satu kesatuan menggantikan yang berhak, Badan dan Bentuk Usaha Tetap (BUT). Dari pasal tersebut dapat dilihat bahwa secara sederhana subjek Pajak Penghasilan adalah orang pribadi dan badan. Sehingga terhadap koperasi sebagai suatu badan yang memiliki usaha sendiri termasuk sebagai subjek Pajak Penghasilan dan memiliki kewajiban untuk membayar Pajak Penghasilan Badan.

Objek Pajak pada Pajak Penghasilan adalah penghasilan. Definisi penghasilan menurut Pasal 4 ayat (1) Undang-Undang Pajak Penghasilan adalah setiap tambahan kemampuan ekonomis yang diterima atau diperoleh Wajib Pajak, baik yang berasal dari Indonesia maupun luar Indonesia, yang dapat dipakai untuk konsumsi atau untuk menambah kekayaan Wajib Pajak yang bersangkutan, dengan nama dan dalam bentuk apapun. Pengertian penghasilan tersebut merupakan penghasilan dalam arti luas, tidak memperhatikan adanya penghasilan dari sumber tertentu melainkan adanya tambahan kemampuan ekonomis sehingga Semua jenis penghasilan yang diterima atau diperoleh dalam suatu tahun pajak digabungkan untuk mendapatkan dasar pengenaan pajak.

Penghasilan yang menjadi Objek Pajak Penghasilan dalam Koperasi adalah : 1. Bunga Simpanan Koperasi

Pajak Penghasilan Atas Bunga Simpanan Koperasi diatur di dalam Peraturan Pemerintah Nomor 15 Tahun 2009. Penghasilan dalam bentuk bunga simpanan merupakan imbalan berbentuk bunga simpanan yang diberikan koperasi kepada anggota atas simpanan wajib dan sukarela yang telah disetorkan. Terhadap bunga simpanan yang dibayarkan oleh koperasi kepada anggota koperasi orang pribadi dikenai Pajak Penghasilan Final yang secara umum diatur di dalam Pasal 4 ayat (2) UU PPh. 


\section{Sisa Hasil Usaha (SHU) Koperasi}

Sisa Hasil Usaha (SHU) Koperasi adalah pendapatan yang diperoleh koperasi dalam satu tahun buku dikurangi dengan pengeluaran atas berbagai beban usaha atau biaya operasional dan kewajiban lainnya termasuk pajak dalam tahun buku yang bersangkutan. Salah satu Objek Pajak Penghasilan berdasarkan Pasal 4 ayat (1) huruf g adalah dalam bentuk dividen, baik dividen dengan nama dan dalam bentuk apapun, termasuk pembagian sisa hasil usaha koperasi. Sehingga dari ketentuan dalam Pasal 4 ayat (1) huruf g tersebut, yang menjadi Objek Pajak Penghasilan adalah pembagian Sisa Hasil Usaha (SHU) koperasi yang diterima oleh anggota koperasi. Pembagian Sisa Hasil Usaha (SHU) koperasi dikenakan Pajak Penghasilan yang bersifat final yang secara umum diatur di dalam Pasal 4 ayat (2) UU PPh.

\section{Pajak Penghasilan Atas Badan Koperasi}

Koperasi sebagai Subjek Pajak Badan perlu melakukan penghitungan Pajak Penghasilan atas badan usaha itu sendiri. Penghitungan Pajak Penghasilan atas Koperasi dimulai dengan menghitung penghasilan neto atau Penghasilan Kena Pajak. Penghasilan Kena Pajak adalah Total Penghasilan setelah dikurangi biaya-biaya terkait.

Secara umum, Pajak Penghasilan Badan dibedakan menjadi dua jenis, yaitu Pajak Penghasilan badan yang bersifat final dan Pajak Penghasilan badan yang tidak final. Pajak Penghasilan Badan yang bersifat final merupakan pajak yang dikenakan dengan tarif dan dasar pengenaan pajak tertentu atas penghasilan yang diterima atau diperoleh suatu badan selama tahun pajak berjalan, sedangkan Pajak Penghasilan badan tidak final merupakan pajak yang pada akhir tahun dihitung ulang dan diperhitungkan dengan kredit pajak yang telah dipotong oleh pihak lain.

Sebagai Subjek Pajak Penghasilan, koperasi memiliki beberapa kewajiban dalam hal Pajak Penghasilan, yaitu meliputi :
a. Pajak Penghasilan Pasal 21;
b. Pajak Penghasilan Pasal 23;
c. Pajak Penghasilan Pasal 25;
d. Pajak Penghasilan Pasal 29;
e. Pajak Penghasilan Final (Pasal 4 ayat (2). 


\section{Pajak Penghasilan Terhadap Koperasi yang Memiliki Peredaran Bruto Tertentu}

Sejak Bulan Juli Tahun 2018, Pemerintah memberlakukan PP Nomor 23 Tahun 2018 tentang Pajak Penghasilan atas Penghasilan dari Usaha yang Diterima atau Diperoleh Wajib Pajak yang Memiliki Peredaran Bruto Tertentu. PP ini mengatur pengenaan Pajak Penghasilan yang bersifat final atas penghasilan yang diperoleh atau diterima oleh Wajib Pajak dengan batasan peredaran bruto tertentu. Ratio legis atau alasan diberlakukannya PP Nomor 23 Tahun 2018 adalah sebagai peraturan pengganti PP Nomor 46 Tahun 2013 yang merupakan peraturan pelaksana dari Pasal 4 ayat (2) huruf e Undang-Undang Pajak Penghasilan terkait Pajak Penghasilan Final serta sebagai upaya untuk mengintensifkan peran serta semua pelaku kegiatan ekonomi terutama pelaku usaha kecil dan menengah untuk membayar pajak, tak terkecuali koperasi. Pengenaan Pajak Penghasilan Final berarti penghasilan yang diterima atau diperoleh akan dikenakan Pajak Penghasilan dengan tarif dan dasar pengenaan tertentu pada saat penghasilan tersebut diterima atau diperoleh Wajib Pajak. Terdapat banyak perubahan ketentuan terkait Pajak Penghasilan Final di dalam PP Nomor 23 Tahun 2018, diantaranya adalah :

1. Penurunan tarif;

2. Penambahan ketentuan jangka waktu;

3. Hak memilih untuk dikenakan PPh Final atau tidak;

4. Penyesuaian kriteria Wajib Pajak Badan;

5. Penyesuaian pengecualian subjek yang dikenai PPh Final;

6. Penegasan omzet untuk Wajib Pajak Orang Pribadi status Pisah Harta dan Penghasilan (PH) dan Memilih Terpisah (MT);

7. Penambahan cara penyetoran yaitu dipotong atau dipungut.

Subjek pajak yang dikenakan Pajak Penghasilan final pada Pasal 3 ayat (1) PP Nomor 23 Tahun 2018 meliputi Wajib Pajak Orang Pribadi dan Badan Usaha berbentuk koperasi, persekutuan komanditer, firma, atau perseroan terbatas yang menerima atau memperoleh penghasilan dengan peredaran bruto tidak lebih dari $\operatorname{Rp} 4,8$ miliar dalam satu tahun pajak. Berbeda halnya dengan pengaturan subjek pajak pada PP Nomor 46 Tahun 2013 yang hanya menyebutkan Wajib Pajak Orang Pribadi dan Wajib Pajak Badan yang menerima penghasilan dari 
usaha, tidak termasuk penghasilan dari jasa sehubungan dengan pekerjaan bebas, dengan peredaran bruto tidak lebih dari Rp 4,8 miliar. Wajib Pajak Badan di dalam PP Nomor 46 Tahun 2013 tidak disebutkan secara jelas Wajib Pajak Badan apa saja yang dapat dikenakan Pajak Penghasilan Final, sedangkan di dalam PP Nomor 23 Tahun 2018 terdapat penyesuaian kriteria Wajib Pajak Badan yakni dengan menyebutkan secara langsung bahwa koperasi yang memiliki peredaran bruto merupakan salah satu Subjek Pajak Badan Pajak Penghasilan Final PP Nomor 23 Tahun 2018.

Objek pajak pada Pajak Penghasilan final dalam PP Nomor 23 Tahun 2018 adalah penghasilan dari usaha yang diterima atau diperoleh Wajib Pajak dalam negeri yang memiliki peredaran bruto tertentu. Yang dimaksud dengan peredaran bruto tertentu dalam Peraturan Pemerintah ini adalah imbalan atau nilai pengganti berupa uang atau nilai uang yang dimiliki atau diperoleh Wajib Pajak sebagaimana kriteria yang telah ditentukan dari usaha sebelum dikurangi potongan penjualan, tunai dan atau potongan sejenis yang tidak melebihi $\operatorname{Rp} 4,8$ miliar dalam satu tahun pajak. Besarnya omzet atau peredaran bruto tertentu tersebut merupakan total dari seluruh outlet atau gerai baik pusat atau cabang dalam satu tahun pajak terakhir sebelum tahun pajak bersangkutan.

Di dalam Pasal 2 ayat (2) dinyatakan bahwa tarif Pajak Penghasilan Final sebesar 0,5\% (nol koma lima persen), sehingga ketentuan tarif tersebut masih dalam batas yang diperbolehkan. Jumlah tarif tersebut lebih rendah dibanding dengan ketentuan tarif Pajak Penghasilan Final sebagaimana diatur di dalam PP Nomor 46 Tahun 2013 yaitu sebesar 1\% (satu persen). Ketentuan tarif 0,5\% tersebut akan tetap dikenakan terhadap Wajib Pajak pada PP 23 Tahun 2018 apabila pada Tahun Pajak berjalan penghasilan dari usaha atau peredaran brutonya telah melebihi $\operatorname{Rp} 4,8$ miliar sampai dengan akhir tahun pajak bersangkutan, kemudian pada tahun pajaktahun pajak berikutnya akan dikenai Pajak Penghasilan berdasarkan tarif umum sebagaimana diatur dalam Pasal 17 ayat (1) huruf a, Pasal 17 ayat (2a) atau Pasal 31E Undang-Undang Pajak Penghasilan. Selain adanya perubahan terhadap jumlah tarif, pemberlakuan jangka waktu terhadap Pajak Penghasilan Final juga diatur di 
dalam PP Nomor 23 Tahun 2018, pengaturan jangka waktu ini dimaksudkan sebagai masa pembelajaran bagi Wajib Pajak untuk melakukan pembukuan sebelum dikenai Pajak Penghasilan dengan rezim umum. Pasal 5 membedakan ketentuan jangka waktu bagi tiap-tiap Subjek Pajak sebagaimana berikut:

a. Terhadap Wajib Pajak Orang Pribadi berlaku jangka waktu tertentu paling lama selama 7 (tujuh) tahun pajak.

b. Terhadap Wajib Pajak Badan berbentuk koperasi, persekutuan komanditer atau firma berlaku jangka waktu tertentu paling lama selama 4 (empat) tahun pajak; dan

c. Terhadap Wajib Pajak Badan berbentuk perseroan terbatas berlaku jangka waktu tertentu paling lama selama 3 (tiga) tahun pajak.

Oleh karena itu, terhadap koperasi yang memiliki peredaran bruto tertentu akan dikenai PajakPenghasilan Final yang berlaku jangka waktu tertentu yaitu paling lama selama 4 (empat) tahun pajak, apabila pada Tahun Pajak berjalan penghasilan dari usaha atau peredaran bruto koperasi telah melebihi $\operatorname{Rp~4,8~miliar~maka~akan~}$ tetap berlaku tarif sebesar 0,5\% sampai dengan akhir Tahun Pajak bersangkutan.

Pasal 4 ayat (1) PMK Nomor 99/PMK.03/2018 menyebutkan bahwa Pajak Penghasilan yang terutang sebagaimana ditentukan dalam PP Nomor 23 Tahun 2018 dapat dilunasi dengan dua cara, yaitu:

a. Disetor sendiri oleh Wajib Pajak.

b. Dipotong atau dipungut oleh pihak lain yang merupakan Pemotong atau Pemungut Pajak sebagaimana yang telah ditunjuk.

koperasi yang memiliki peredaran bruto tertentu dapat menyetorkan Pajak Penghasilan Finalnya sendiri setiap bulan di setiap tempat kegiatan usahanya. Penyetoran tersebut paling lambat pada tanggal 15 bulan berikutnya setelah masa pajak berakhir dengan menggunakan Kode Billing. Terkait penyetoran Pajak Penghasilan sendiri setiap bulannya tidak perlu melaporkan pembayarannya karena telah dianggap menyampaikan Surat Pemberitahuan Masa Pajak Penghasilan sesuai dengan tanggal validasi Nomor Transaksi Penerimaan Negara yang ada pada Surat Setoran Pajak (SSP)nya. 
Koperasi juga dapat melakukan pelunasan terhadap Pajak Penghasilan Finalnya dengan cara dipotong atau dipungut oleh pihak lain. Menurut Pasal 1 Angka 3 PP Nomor 23 Tahun 2018, Pemotong atau pemungut pajak adalah Wajib Pajak yang dikenakan kewajiban untuk melakukan pemotongan dan/atau pemungutan pajak sesuai dengan ketentuan peraturan perundang-undangan di bidang Pajak Penghasilan. Pemotong atau Pemungut tersebut harus melalui keputusan penunjukan sebagai Pemotong atau Pemungut Pajak Penghasilan Final oleh Kantor Pelayanan Pajak (KPP) tempatnya terdaftar. Koperasi sebagai Wajib Pajak yang akan dipotong atau dipungut wajib mengajukan permohonan ke KPP untuk diterbitkan Surat Keterangan yang menerangkan bahwa koperasi tersebut dikenai PPh Final PP Nomor 23 Tahun 2018. Berbeda halnya dengan PP Nomor 46 Tahun 2013 yang tidak mengatur mengenai Surat Keterangan, di dalam PP Nomor 46 Tahun 2013 dikenal yang namanya Surat Keterangan Bebas yang digunakan untuk membebaskan pemotongan dan/atau pemungutan terhadap Pajak Penghasilan Pasal 21, 22 atau 23 oleh pihak lain dengan pengajuan legalisir ke KPP terdaftar. Di dalam Pasal 6 ayat (1) PMK Nomor 107/PMK.011/2013 dijelaskan bahwa bagi Wajib Pajak yang berdasarkan Ketentuan UU PPh dan peraturan pelaksananya wajib dilakukan pemotongan dan/atau pemungutan Pajak Penghasilan yang tidak bersifat final oleh pihak lain maka dapat dibebaskan dalam hal Wajib Pajak dapat menunjukkan Surat Keterangan Bebas ke KPP.

Terhadap penghasilan yang telah dikenakan Pajak Penghasilan Final tidak perlu digabungkan dan dihitung lagi dengan penghasilan lainnya untuk dikenakan tarif umum di SPT Tahunan karena dikenakan langsung ketika terjadi transaksi oleh Wajib Pajak. Pajak yang sudah disetor sendiri maupun dipotong atau dipungut pihak lain juga bukanlah kredit pajak di SPT Tahunan.

Pajak Penghasilan Final yang diatur di dalam PP Nomor 23 Tahun 2018 bersifat opsional, koperasi dengan peredaran bruto tertentu sebagai Wajib Pajak Badan PPh Final diberikan hak memilih untuk dikenai PPh Final dengan ketentuan PP Nomor 23 Tahun 2018 atau dikenai Pajak Penghasilan berdasarkan Pasal 17 ayat (2a) dan Pasal 31E Undang-Undang Pajak Penghasilan sebagai 
Wajib Pajak Badan. Hal tersebut berbeda dengan ketentuan di dalam PP Nomor 46 Tahun 2013, Pajak Penghasilan Final yang diatur di dalam PP tersebut tidak bersifat opsional, sehingga bagi Wajib Pajak yang memiliki peredaran bruto tertentu kurang dari Rp 4,8 miliar wajib membayar Pajak Penghasilan Final, dan bagi Wajib Pajak yang memiliki peredaran bruto melebihi Rp 4,8 miliar wajib membayar Pajak Penghasilan dengan skema tarif Pasal 17 UU PPh. Bagi koperasi yang memiliki peredaran bruto tertentu memilih untuk tidak dikenai PPh Final PP Nomor 23 Tahun 2018 dan memilih untuk dikenai Pajak Penghasilan dengan tarif umum berdasarkan Ketentuan Umum Pajak Penghasilan, wajib menyampaikan pemberitahuan secara tertulis kepada Direktur Jenderal Pajak paling lambat pada akhir Tahun Pajak.

\section{Pajak Penghasilan Terhadap Koperasi yang Memiliki Peredaran Bruto Tidak Tertentu}

Jika dilihat dari jumlah omzet yang dimiliki, maka Wajib Pajak Badan koperasi dibedakan menjadi tiga, yaitu:

1. Wajib Pajak Badan koperasi dengan omzet di bawah Rp 4,8 miliar per tahun;

2. Wajib Pajak Badan koperasi dengan omzet lebih besar dari Rp 4,8 miliar dan kurang dari Rp 50 miliar per tahun;

3. Wajib Pajak Badan koperasi dengan omzet lebih dari Rp 50 miliar per tahun.

Koperasi yang memiliki peredaran bruto (omzet) lebih dari Rp 4,8 miliar dalam satu tahun pajak (baik koperasi dengan omzet lebih besar dari Rp 4,8 miliar dan kurang dari Rp 50 miliar per tahun maupun koperasi dengan omzet lebih dari Rp 50 miliar per tahun) bukanlah termasuk sebagai koperasi yang memiliki peredaran bruto tertentu sehingga koperasi tersebut tidak dikenakan Pajak Penghasilan PP Nomor 23 Tahun 2018. Namun koperasi yang memiliki peredaran bruto tidak tertentu dikenai Pajak Penghasilan berdasarkan Ketentuan Umum Pajak Penghasilan, yaitu Pajak Penghasilan Pasal 25. Sejak diberlakukannya PP Nomor 23 Tahun 2018 dan PMK Nomor 99/PMK.03/2018 yang memberikan opsi bagi Wajib Pajak terhadap Pajak Penghasilan Final, maka Pajak Penghasilan Pasal 25 tersebut tidak hanya berlaku bagi koperasi yang memiliki peredaran 
bruto tidak tertentu. Dengan adanya ketentuan di dalam Pasal 9 ayat (1) PMK Nomor 99/PMK.03/2018 maka Wajib Pajak Badan Koperasi yang mulai Tahun Pajak pertama wajib membayar Angsuran Pajak Penghasilan Pasal 25 berdasarkan Ketentuan Umum Pajak Penghasilan adalah :

a. Wajib Pajak yang memiliki peredaran bruto melebihi Rp 4,8 miliar pada suatu Tahun Pajak atau dikatakan sebagai koperasi dengan peredaran bruto tidak tertentu,

b. Wajib Pajak yang memiliki peredaran bruto tertentu dan memilih untuk dikenai PPh berdasarkan Ketentuan Umum Pajak Penghasilan, dan;

c. Wajib Pajak PPh Final PP Nomor 23 Tahun 2018 yang telah melewati jangka waktu tertentu sebagaimana ditentukan dalam PP Nomor 23 Tahun 2018. Sehingga selain koperasi yang memiliki peredaran bruto tidak tertentu, berdasarkan ketentuan tersebut maka koperasi yang memiliki peredaran bruto tertentu namun memilih untuk dikenai PPh berdasarkan Ketentuan Umum Pajak Penghasilan serta koperasi sebagai Wajib Pajak Badan PPh Final PP Nomor 23 Tahun 2018 yang telah melewati jangka waktu 4 tahun pajak maka akan dikenai Pajak Penghasilan Pasal 25. Pengaturan tersebut bertujuan untuk lebih memberikan keadilan kepada Wajib Pajak.

Terhadap koperasi yang memiliki peredaran bruto tertentu dan memilih untuk dikenai Pajak Penghasilan Pasal 25 oleh pemerintah diberikan fasilitas pengurangan tarif terhadap Pajak Penghasilan Badannya. Di dalam Pasal 31E UU Pajak Penghasilan fasilitas berupa pengurangan tarif sebesar 50\% dari tarif pada Pasal 17 ayat (2a) yaitu sebesar 25\% yang dikenakan atas Penghasilan Kena Pajak dari bagian peredaran bruto sampai dengan Rp 4,8 miliar, pengurangan tarif tersebut diberikan kepada Wajib Pajak Badan dalam negeri yang memiliki peredaran bruto sampai dengan Rp 50 miliar. Kebijakan fasilitas pengurangan tarif pajak ini didasarkan pada prinsip keadilan dan peningkatan daya saing pada Wajib Pajak Badan agar dapat semakin mudah berkembang.

Sebagai contoh, Koperasi Gubeng yang bergerak dibidang usaha dagang pada Tahun 2019 memiliki penerimaan bruto (omzet) dalam setahun sebesar 
Rp500.000.000 dan seluruh biaya-biaya yang berkaitan dengan usaha (seperti biaya pembelian bahan, biaya berkenaan dengan pekerjaan atau jasa dan lainlain yang sesuai dengan ketentuan perpajakan) sebesar Rp425.000.000. Koperasi Gubeng memilih untuk dikenai Pajak Penghasilan Badan berdasarkan ketentuan Pasal 25. Diketahui bahwa Penghasilan Kena Pajak Koperasi Gubeng adalah sebesar Rp500.000.000 - Rp425.000.000 = Rp75.000.000. Karena Koperasi Gubeng memiliki omzet di bawah Rp 4,8 miliar dan memilih untuk dikenai PPh Badan berdasarkan ketentuan Pajak Penghasilan Pasal 25, maka Koperasi Gubeng berhak untuk mendapatkan fasilitas pengurangan tarif Pajak Penghasilan sehingga Pajak Penghasilan yang terutang adalah Rp75.000.000 × 25\% x 50\% = Rp9.375.000. Dan angsuran PPh Pasal 25 yang harus dibayar oleh Koperasi Gubeng setiap bulannya adalah Rp9.375.000 dibagi $12=$ Rp781.250.

Sehingga berdasarkan pemaparan di atas maka terdapat 3 klasifikasi tarif Pajak Penghasilan yang berlaku bagi Wajib Pajak Badan Koperasi berdasarkan tingkat peredaran brutonya, yaitu sebagai berikut:

1. Terhadap koperasi yang memiliki peredaran bruto tertentu (penghasilan bruto kurang dari Rp 4.8 miliar), maka tarif pajaknya adalah sebesar 0,5\% dikalikan dengan peredaran brutonya. Namun apabila koperasi tersebut memilih untuk dikenai Pajak Penghasilan Pasal 25 maka tarif pajaknya berdasarkan ketentuan Pasal 17 ayat (2a) dan Pasal 31E UU PPh yakni sebesar 25\% dan memperoleh fasilitas pengurangan tarif sebesar $50 \%$, sehingga perhitungannya adalah $50 \%$ x 25\% dikalikan dengan Penghasilan Kena Pajak.

2. Terhadap koperasi yang memiliki penghasilan lebih dari Rp 4,8 miliar sampai dengan Rp 50 miliar, maka tarif pajak yang berlaku adalah $(50 \%$ × 25\% dikalikan dengan Penghasilan Kena Pajak yang memperoleh fasilitas) + (25\% x Penghasilan Kena Pajak yang tidak memperoleh fasilitas)

3. Terhadap koperasi yang memiliki penghasilan lebih dari Rp 50 miliar, maka tarif yang dikenakan adalah sebesar 25\% dan perhitungannya adalah $25 \% \mathrm{x}$ Penghasilan Kena Pajak. 


\section{Perlindungan Hukum Bagi Koperasi Atas Pemungutan Pajak Penghasilan}

Dalam pemungutan pajak penghasilan haruslah mencerminkan keadilan bagi para pihaknya yakni dengan mengindahkan keempat asas pemungutan pajak "The Four Cannons Maxims Taxation" yang dikemukakan oleh Adam Smith yaitu asas Equity and Equality (kesamaan dan keadilan), asas Certainly (kepastian hukum), asas Convenience of Payment (Pemungutan Pajak Tepat Waktu), dan asas Eficiency/Economic of Collections (Efisiensi). Adapun asas yang relevan dalam pokok bahasan ini adalah:

\section{Equity and Equality}

Asas ini menekankan bahwa dalam memungut pajak tidak diperkenankan bertindak diskriminatif, asas kesamaan di sini bukanlah sama rata namun proporsional yakni secara seimbang sesuai dengan kemampuan Wajib Pajak sebagaimana diketahui bahwa Wajib Pajak memiliki kemampuan ekonomi yang berbeda-beda. Berdasarkan uraian terkait pemungutan pajak penghasilan di atas maka pemungutan pajak penghasilan terhadap badan koperasi telah mencerminkan asas Equality. Pemungutan pajak penghasilan tersebut telah disesuaikan dengan jumlah omzet yang diperoleh koperasi dalam satu tahun pajak, terhadap koperasi yang memiliki omzet rendah dikenai tarif pajak yang lebih rendah dibandingkan dengan koperasi yang memiliki omzet besar. Namun bagikoperasi yang memiliki omzet besar pemerintah tetap memberikan fasilitas pengurangan tarif untuk meringankan beban pajaknya.

\section{Certainly}

Asas ini menekankan bahwa bagi Wajib Pajak, harus jelas tentang waktu, jumlah dan cara pembayaran pajak. Dalam asas ini kepastian hukum sangat dipentingkan. Terkait pemungutan pajak penghasilan bagi badan koperasi, telah diatur berbagai macam peraturan perundang-undangan yang mengatur mengenai subjek, objek, waktu, tarif serta cara pembayaran pajaknya sehingga terdapat kepastian hukum terkait pemungutan pajak penghasilan badan koperasi. Sebagai contoh adalah dengan diberlakukannya PMK Nomor 99/ PMK.03/2018 yang mengatur tentang tata cara pemberitahuan bagi Wajib Pajak 
yang memilih untuk dikenai pajak penghasilan berdasarkan ketentuan umum pajak penghasilan, tata cara penyetoran, pemotongan atau pemungutan, dan pelaporan Pajak Penghasilan Final, pengajuan permohonan dan penerbitan surat keterangan

Selain pemungutan pajak yang harus mencerminkan keadilan, sebagaimana di dalam pembukaan UUD 1945 alinea keempat yang menyatakan bahwa Indonesia sebagai suatu negara bertujuan untuk melindungi setiap bangsa dan seluruh tumpah darah Indonesia, maka negara berkewajiban untuk melindungi seluruh komponen bangsa Indonesia termasuk Wajib Pajak. Perlindungan hukum terhadap Wajib Pajak dalam pemungutan pajak merupakan suatu konsekuensi hukum bagi Indonesia sebagai negara hukum. Perlindungan hukum erat kaitannya dengan upaya untuk menciptakan suatu keadilan. Wajib Pajak Koperasi dalam hal pemungutan pajak penghasilan diberikan perlindungan hukum preventif dan represif.

Perlindungan preventif di sini adalah dengan mengajukan keberatan. Dalam hal koperasi sebagai Wajib Pajak Badan merasa keberatan dengan suatu keputusan pemerintah, maka koperasi memiliki hak untuk mengajukan keberatan terhadap tindakan pemerintah tersebut, termasuk terhadap pemungutan Pajak Penghasilan bagi koperasi. Di dalam Pasal 25 ayat (1) UU Ketentuan Umum dan Tata Cara Perpajakan diatur mengenai hak bagi Wajib Pajak untuk mengajukan keberatan kepada Direktur Jenderal Pajak. Koperasi sebagai Wajib Pajak dapat mengajukan keberatan apabila koperasi merasa atau berpendapat bahwa ketetapan jumlah rugi, jumlah pajak, dan pemotongan atau pemungutan pajak tidak sebagaimana mestinya. Pasal ini memberikan batasan terkait objek yang dapat diajukan keberatan, yaitu meliputi :

1. Wajib Pajak hanya dapat mengajukan keberatan hanya kepada Direktur Jenderal Pajak atas suatu :
a. Surat Ketetapan Pajak Kurang Bayar;
b. Surat Ketetapan Pajak Kurang Bayar Tambahan;
c. Surat Ketetapan Pajak Nihil;
d. Surat Ketetapan Pajak Lebih Bayar; atau
e. Pemotongan atau pemungutan pajak oleh pihak ketiga berdasarkan ketentuan peraturan perundang-undangan perpajakan.


Yang dapat mengajukan keberatan bagi koperasi sebagai Wajib Pajak Badan adalah pengurus koperasi atau kuasa hukumnya. Keberatan dapat diajukan kepada Kepala Kantor Pelayanan Pajak (KPP) di tempat di mana Wajib Pajak koperasi terdaftar. Koperasi sebagai Wajib Pajak Badan hanya dapat mengajukan keberatan terhadap materi atau isi dari Surat Ketetapan Pajak meliputi jumlah rugi berdasarkan ketentuan peraturan perundang-undangan perpajakan, jumlah besarnya pajak, atau terhadap materi atau isi dari pemotongan atau pemungutan pajak yang dianggap tidak sesuai. Selain diatur di dalam Pasal 25 KUP, pengajuan keberatan diatur di dalam Peraturan Menteri Keuangan Republik Indonesia No 202/PMK.03/2015 tentang Tata Cara Pengajuan dan Penyelesaian Keberatan yang merupakan penyempurnaan dari PMK No 9/PMK.03/2013.

Sebagai contoh adalah sebagai berikut. Pada tanggal 10 Juni 2018, Koperasi Dharmawangsa menerima Surat Ketetapan Pajak Lebih Bayar (SKPLB) yang diterbitkan oleh KPPSurabaya. Dalam surat ketetapan tersebut menyatakan bahwa berdasarkan pemeriksaan yang telah dilakukan oleh KPP Surabaya jumlah pajak lebih bayar Koperasi Dharmawangsa adalah sebesar Rp280.000.000, sedangkan berdasarkan perhitungan yang dilakukan oleh Koperasi Dharmawangsa seharusnya lebih bayar sebesar Rp580.000.000. Oleh karena alasan tersebut, Koperasi Dharmawangsa dapat melakukan upaya hukum dengan mengajukan keberatan secara tertulis melalui surat keberatan yang di dalamnya mencakup alasan-alasan keberatan tersebut disertai dengan bukti-bukti.

Terkait penyelesaian sengketa pajak, koperasi sebagai Wajib Pajak dapat menempuh upaya hukum yaitu dengan mengajukan banding dan gugatan kepada pengadilan. Dengan berlakunya UU No. 14 tahun 2002 tentang Pengadilan pajak maka sistem peradilan pajak dalam proses penyelesaian sengketa pajak dapat dilakukan melalui Pengadilan Pajak. Berdasarkan Pasal 1 angka 6 UU Nomor 14 Tahun 2002 tentang Pengadilan Pajak, banding adalah upaya hukum yang dapat dilakukan oleh Wajib Pajak atau penanggung Pajak terhadap suatu keputusan yang dapat diajukan banding, berdasarkan peraturan perundang-undangan perpajakan yang berlaku. Putusan Banding 
adalah putusan Badan Peradilan Pajak atas banding terhadap Surat Keputusan Keberatan yang diajukan oleh Wajib Pajak.

Wajib Pajak dapat mengajukan permohonan banding atas Surat Keputusan Keberatan kepada Badan Peradilan Pajak. Setelah dikeluarkannya Surat Keputusan Keberatan oleh Direktur Jenderal Pajak namun koperasi sebagai Wajib Pajak masih belum puas dengan keputusan keberatan yang telah diajukannya, maka koperasi dapat mengajukan permohonan banding ke Badan Peradilan Pajak atas Surat Keputusan Keberatan tersebut. Sehingga banding pada hakikatnya merupakan kelanjutan dari sengketa pajak pada tahap keberatan, namun yang dipersengketakan dalam banding adalah materi dari Surat Keputusan Keberatan. Sehingga diketahui bahwa objek banding adalah sengketa atas keputusan keberatan.

Sebagai contoh adalah sebagaimana berikut. Pada tanggal 8 Desember 2018, KPPSurabaya menerbitkan Surat Keputusan Keberatan Nomor: KEP-101/WPJ.10/ BD.12/2018 tentang Keberatan atas SKPLB PPh Badan Koperasi Dharmawangsa Tahun 2018, keberatan atas SKPLB PPh Badan Koperasi tersebut dinyatakan ditolak seluruhnya dan menetapkan jumlah PPh Badan Koperasi Dharmawangsa lebih dibayar sebesar Rp28.000.000, sedangkan menurut Koperasi Dharmawangsa seharusnya lebih bayar sebesar Rp580.000.000. Atas Surat Keputusan Keberatan tersebut Koperasi dapat mengajukan banding ke Pengadilan Pajak melalui Surat Banding yang di dalamnya dijelaskan alasan-alasan mengajukan banding, perhitungan pajak menurut Koperasi Dharmawangsa, dilampiri dengan Surat Keputusan Keberatan dan bukti-bukti lainnya.

Selain upaya hukum banding, koperasi sebagai Wajib Pajak Badan juga mendapatkan perlindungan hukum represif melalui upaya hukum gugatan. Menurut Pasal 1 angka 7 Undang-undang No. 14 Tahun 2002 tentang Pengadilan Pajak, gugatan adalah upaya hukum yang dapat dilakukan oleh wajib pajak atau penanggung pajak terhadap pelaksanaan penagihan pajak atau terhadap keputusan yang dapat diajukan gugatan berdasarkan peraturan perundangundangan perpajakan yang berlaku. Gugatan dapat dilakukan oleh Wajib Pajak atau Penanggung Pajak kepada Badan Peradilan Pajak. Berdasarkan Pasal 31 
ayat (3) UU Nomor 14 Tahun 2002 jo. Pasal 23 (2) UU KUP, yang dapat diajukan gugatan oleh wajib pajak atau penanggung pajak meliputi:

1. Pelaksanaan surat paksa, surat perintah melakukan penyitaan, atau pengumuman lelang;

2. Keputusan pencegahan dalam rangka penagihan pajak;

3. Keputusan yang berkaitan dengan pelaksanaan keputusan perpajakan, selain yang ditetapkan dalam Pasal 25 ayat (1) dan 26; atau

4. Penerbitan surat ketetapan pajak atau surat keputusan keberatan yang dalam penerbitannya tidak sesuai dengan prosedur atau tata cara yang telah diatur dalam ketentuan peraturan perundang-undangan perpajakan.

Sebagai contoh adalah sebagai berikut. Pada tanggal 17 Juli 2019, Koperasi Dharmawangsa menerima Surat Keputusan Nomor: KEP-00022/PPH-25/ WPJ.20/KP.0703/2019 tentang Besarnya Pajak Penghasilan Pasal 25 Koperasi Dharmawangsa Masa Pajak Juli sampai dengan Desember 2019 yang dikeluarkan oleh KPP Surabaya, sedangkan permohonan pengurangan Angsuran Pajak Penghasilan Pasal 25 yang diajukan oleh Koperasi Dharmawangsa telah diterima oleh KPP Surabaya pada tanggal 11 Juni 2019. Bahwa dengan telah lengkapnya permohonan pengurangan besarnya Penghasilan Pasal 25 masa Juli sampai dengan Desember 2019 pada tanggal 11 Juni 2019, maka sesuai Pasal 6 ayat (4) KPP Surabaya harus menerbitkan surat keputusan tentang besarnya Pajak Penghasilan Pasal 25 Masa Pajak Juli sampai dengan Desember 2009 paling lambat tanggal 1 Juli 2019 (15 hari kerja sejak tanggal 11 Juni 2019 tanggal pengajuan diterima lengkap). Karena sampai dengan tanggal 1 Juli 2009, KPP Surabaya belum menerbitkan keputusan dan Surat Keputusan Nomor : KEP-00022/PPH25/WPJ.20/ KP.0703/2009 baru diterbitkan oleh KPP Surabaya pada tanggal 17 Juli 2019, dengan demikian penerbitan Keputusan Nomor : KEP-00022/PPH25/ WPJ.20/KP.0703/2019 tanggal 17 Juli 2019 Tentang Besarnya Pajak Penghasilan Koperasi Dharmawangsa Pasal 25 Masa Pajak Juli sampai dengan Desember 2019 tidaklah memenuhi Syarat Formal. Sehingga atas Surat Keputusan tersebut berdasarkan Pasal 31 ayat (3) UU Nomor 14 Tahun 2002 jo. Pasal 23 (2) UU KUP yang menyatakan bahwa salah satu yang dapat diajukan gugatan adalah surat keputusan yang dalam penerbitannya tidak sesuai dengan prosedur atau tata cara 
yang telah diatur dalam ketentuan peraturan perundang-undangan perpajakan maka Koperasi Dharmawangsa dapat mengajukan gugatan kepada Pengadilan Pajak secara tertulis.

Apabila koperasi merasa bahwa putusan Pengadilan Pajak dianggap kurang atau bahkan tidak mencerminkan keadilan maka atas putusan tersebut koperasi dapat mengajukan Peninjauan Kembali (PK) kepada Mahkamah Agung. Sebagaimana ketentuan di dalam Pasal 33 ayat (1) Undang-Undang Nomor 14 Tahun 2002, Pengadilan Pajak merupakan pengadilan pada tingkat pertama dan tingkat terakhir dalam memeriksa dan memutus sengketa pajak. Sehingga di dalam penyelesaian sengketa pajak tidaklah dikenal kasasi, namun upaya hukum yang dapat dilakukan terhadap putusan banding maupun putusan gugatan Pengadilan Pajak adalah Peninjauan Kembali ke Mahkamah Agung.

\section{Kesimpulan}

Pertama setelah diberlakukannya PP Nomor 23 Tahun 2018 dan PMK Nomor 99/PMK.03/2018 terdapat perbedaan pengenaan Pajak Penghasilan bagi koperasi sebagai Wajib Pajak Badan. Pemungutan Pajak Penghasilan terhadap koperasi telah mencerminkan keadilan jika ditinjau dari jumlah omzet yang diterima, koperasi sebagai Wajib Pajak Badan tidak lagi dibingungkan dengan pengaturan terkait fasilitas pengurangan tarif dalam Pasal 31E UU PPh dan PP Nomor 46 Tahun 2013. Jika ditinjau berdasarkan jumlah omzetnya, terhadap koperasi yang memiliki peredaran bruto tertentu yakni omzet di bawah $\operatorname{Rp} 4,8$ miliar per tahun akan dikenakan PPh final berdasarkan ketentuan PP Nomor 23 Tahun 2018, namun apabila koperasi tersebut memilih untuk dikenai PPh Pasal 25 maka tarif pajaknya mengikuti ketentuan Pasal 17 ayat (2a) dan Pasal 31E Undang-Undang Nomor 36 Tahun 2008 yang dikenakan dari penghasilan netonya. Koperasi yang memiliki peredaran bruto tidak tertentu dengan omzet lebih dari Rp 4,8 miliar sampai dengan Rp 50 miliar juga dikenakan tarif pajak dengan ketentuan Pasal 17 ayat (2a) dan Pasal 31E Undang-Undang Nomor 36 Tahun 2008. Sedangkan terhadap koperasi yang memiliki penghasilan lebih dari Rp 50 miliar akan dikenakan PPh 
Pasal 25 dengan tarif pajak berdasarkan ketentuan Pasal 17 ayat (2a) UndangUndang Nomor 36 Tahun 2008.

Kedua perlindungan hukum bagi koperasi sebagai Wajib Pajak Badan atas pemungutan Pajak Penghasilan meliputi perlindungan hukum preventif dan represif. Terkait perlindungan hukum preventif, koperasi dapat mengajukan keberatan. Terkait perlindungan hukum represif, koperasi yang dalam hal ini diwakili oleh pengurus atau kuasa hukumnya dapat menempuh upaya hukum yaitu dengan mengajukan banding atau gugatan kepada pengadilan dan apabila koperasi merasa bahwa putusan Pengadilan Pajak dianggap kurang atau bahkan tidak mencerminkan keadilan maka atas putusan tersebut koperasi dapat mengajukan Peninjauan Kembali kepada Mahkamah Agung.

\section{Daftar Bacaan}

\section{Buku}

Adrian Sutedi, Hukum Pajak (Sinar Grafika).

Burton WBI dan R, Hukum Pajak (Salemba Empat 2010).

Muslimin Nasution, Koperasi Menjawab Kondisi Ekonomi Nasional (Pusat Informasi perkoperasian 2008).

\section{Laman}

Gabriella Thesa Widiari, 'PDB Koperasi Indonesia Terus Meningkat', (Gesuri.id 2019) <https://www.gesuri.id/pemerintahan/pdb-koperasi-indonesiaterus-meningkat-b1WcBZimr > accessed 2 Agustus 2019.

Media Indonesia, 'Empat Tahun Reformasi Total Koperasi', (Media Indonesia 2018)<https: / / mediaindonesia.com/read/detail/191881-empat-tahunreformasi-total-koperasi> accessed 2 Agustus 2019.

\section{Perundang-Undangan}

Undang-Undang Dasar Negara Republik Indonesia Tahun 1945.

Undang-Undang Republik Indonesia Nomor 25 Tahun 1992 tentang Perkoperasian.

Undang-Undang Republik Indonesia Nomor 6 Tahun 1983 tentang Ketentuan 
Umum dan Tata Cara Perpajakan Sebagaimana Telah Beberapa Kali Diubah Terakhir Dengan Undang-Undang Nomor 16 Tahun 2009.

Undang-Undang Republik Indonesia Nomor 14 Tahun 2002 tentang Pengadilan Pajak.

Undang-Undang Republik Indonesia Nomor 36 Tahun 2008 tentang Perubahan Keempat Atas Undang-Undang Nomor 7 Tahun 1983 tentang Pajak Penghasilan.

Peraturan Pemerintah Republik Indonesia Nomor 46 Tahun 2013 tentang Pajak Penghasilan Atas Penghasilan dari Usaha yang Diterima atau Diperoleh Wajib Pajak yang Memiliki Peredaran Bruto Tertentu.

Peraturan Menteri Keuangan Republik Indonesia Nomor 107/PMK.011/2013 Tentang Tata Cara Penghitungan, Penyetoran, Dan Pelaporan Pajak Penghasilan Atas Penghasilan Dari Usaha yang Diterima atau Diperoleh Wajib Pajak yang Memiliki Peredaran Bruto Tertentu.

Peraturan Pemerintah Republik Indonesia Nomor 23 Tahun 2018 Tentang Pajak Penghasilan Atas Penghasilan Dari Usaha yang Diterima Atau Diperoleh Wajib Pajak yang Memiliki Peredaran Bruto Tertentu.

Peraturan Menteri Keuangan Republik Indonesia Nomor 99/PMK.03/2018 Pelaksanaan Peraturan Pemerintah Nomor 23 Tahun 2018 Tentang Pajak Penghasilan Atas Penghasilan Dari Usaha yang Diterima Atau Diperoleh Wajib Pajak yang Memiliki Peredaran Bruto Tertentu. 
254 | Roidah Zahiroh: Keabsahan Pemungutan Pajak...

--Halaman ini sengaja dikosongkan-- 